ISSN 1979-5572 (print)

ISSN 2541-6480 (online

http://ejurnal.iainpare.ac.id/index.php/kuriositas

KURIOSITAS

Media Komunikasi Sosial dan Keagamaan

Volume 11

No. 1, Juni 2018

Halaman 19-32

\title{
PEMBELAJARAN QUANTUM TEACHING MENINGKATKAN MINAT BELAJAR AQIDAH AKHLAK BAGI SISWA MADRASAH
}

\author{
Ibrahim \\ MTs DDI Kaballangan \\ ibrakaballangan@gmail.com
}

\begin{abstract}
This article aims to determine the intensity of the implementation of quantum teaching, the interest in learning Aqidah Akhlak. This type of research is field research and includes quantitative research. Data obtained through observation, questionnaires and documentation. Data were analyzed descriptively and inferentially, using statistical processing software. The results of this study were, (1) The intensity of the implementation of Quantum teaching, was in the low category. (2) The interest in learning Aqidah Akhlak learners (variable $Y$ ) is in the high category. (3) The results of the hypothesis test concluded that there is an effect of quantum teaching on the learning interests of Aqidah Akhlak MTs students in DDI Manahilil Ulum Kaballangan Islamic Boarding School Pinrang Regency. The implications of this study are, it is expected that educators, to always strive to be professional educators by attending seminars, training, workshops, comparative studies to institutions that are central to learning Quantum Teaching.
\end{abstract}

Keywords: Quantum teaching, akidah akhlak, learning 


\begin{abstract}
ABSTRAK
Artikel ini bertujuan untuk mengetahui intensitas pelaksanaan quantum teaching, minat belajar Aqidah Akhlak. Jenis penelitian ini adalah penelitian lapangan dan termasuk penelitian kuantitatif. Data diperoleh melalui observasi, kuesioner dan dokumentasi. Data dianalisis secara deskriptif dan inferensial, dengan bantuan software pengolahan statistik. Adapun hasil penelitian ini yaitu, (1) Intensitas pelaksanaan Quantum teaching, termasuk kategori rendah. (2) Minat belajar Aqidah Akhlak peserta didik (variabel Y) termasuk kategori tinggi. (3) Hasil uji hipotesis dapat disimpulkan bahwa terdapat pengaruh quantum teaching terhadap minat belajar Aqidah Akhlak peserta didik MTs Pondok Pesantren DDI Manahilil Ulum Kaballangan Kabupaten Pinrang. Adapun implikasi pada penelitian ini adalah, diharapkan bagi pendidik, untuk selalu berupaya menjadi pendidik yang profesional dengan cara mengikuti seminar, pelatihan, Workshop, Studi banding kepada lembaga yang menjadi sentral pembelajaran Quantum Teaching.

Kata Kunci: Quantum teaching, aqidah akhlak, pembelajaran
\end{abstract}

\title{
PENDAHULUAN
}

Salah satu upaya seorang guru untuk meningkatkan mutu pendidikan adalah penggunaan metode pembelajaran yang tepat dalam menyampaikan materi pelajaran. Bagi peserta didik yang belum dapat menerima materi yang disampaikan guru, maka penggunaan metode yang tepat sangat dianjurkan. Dengan demikian penggunaan metode untuk menyampaikan materi pembelajaran akan lebih dihayati tanpa menimbulkan kesalahpahaman bagi keduanya yaitu peserta didik dan guru.

Metode adalah suatu cara mengajar yang berfungsi sebagai alat untuk mencapai tujuan pembelajaran. Semakin baik metode yang digunakan, maka akan semakin efektif dan efisien pula pencapaian tujuannya. Dalam metode mangajar, faktor guru, peserta didik, bahan yang 
akan diajarkan, situasi, sarana, prasarana, serta fasilitas-fasilitas lainnya sangat besar pengaruhnya.

Terdapat banyak faktor yang mempengaruhi di dalam penggunaan suatu metode, maka sebenarnya cukup sulit bagi seorang guru untuk menetapkan metode yang paling tepat dipakai di dalam pembelajaran agar pembelajaran tersebut berhasil. Mata pelajaran Aqidah Akhlak ini kurang mendapat perhatian bahkan diremehkan oleh sebagian peserta didik, karena mereka sudah merasa bisa tentang agama. Untuk itu perlu diterapkan suatu cara alternatif guna meningkatkan minat bakat, dan motivasi peserta didik untuk mengembangkan potensi berkreativitas sehingga menghasilkan prestasi yang optimal. Salah satu alternatif yang digunakan adalah dengan mengubah metode pembelajaran yang menarik untuk mempelajari Pendidikan Agama Islam yang menyenangkan dan lebih mudah dipahami peserta didik serta meningkatkan motivasi belajar peserta didik dalam proses belajar mengajar Aqidah Akhlak. Maka dari itu peserta didik akan lebih banyak menerapkan dalam kehidupan sehari-hari.

Quantum Teaching adalah suatu pembelajaran yang dirancang untuk memudahkan peserta didik untuk belajar. Pembelajaran Quantum Teaching merupakan pembelajaran yang dirancang untuk membuat peserta didik senang dari permulaan sampai akhir pelajaran. Dengan keadaan yang menyenangkan tersebut peserta didik tidak merasa terbebani dalam menerima pelajaran, karena dalam pembelajaran Quantum Teaching dirancang sedemikian rupa sehingga siapapun yang mengikuti pelajaran akan merasa senang. Dengan keadaan yang menggembirakan itu semua materi yang diberikan oleh guru akan mudah diterima oleh peserta didik. Dan metode Quantum Teaching merupakan salah satu metode yang dapat dipakai dalam proses pembelajaran agama. Cara penerapannya adalah dengan metode Quantum Teaching karena guru sebagai motivator yang dapat membangkitkan kesadaran peserta didik.

Tujuan dari Quantum Teaching adalah untuk menghindari dari suasana kegiatan pembelajaran yang menjenuhkan, dan tentunya memberi 
prestasi belajar yang gemilang terhadap peserta didik serta mencetak peserta didik yang tak hanya memiliki keterampilan akademik tetapi juga memiliki keterampilan hidup "life skill". Dengan metode ini diharapkan agar peserta didik lebih mudah memahami materi pelajaran Aqidah Akhlak sekaligus dapat meningkatkan motivasi belajar peserta didik dalam proses belajar mengajar Aqidah Akhlak.

Efektifitas penggunaan Quantum Teaching pada pembelajaran tergantung pada kemampuan guru dalam mengelola pembelajaran, metode menyajikan model yang bervariasi misalnya: metode "Sosio Drama" kejadian yang ada dalam kehidupan sehari-hari, maka peserta didik akan dapat mengekspresikan dengan berkreasi melalui imajinasinya, peserta didik akan mempunyai gambaran tentang cerita tersebut dan paham betul dengan isi ceritanya. Peserta didik akan lebih paham lagi jika diputarkan film atau video yang menceritakan tentang isi materi tersebut, kemudian diadakan tanya jawab. Dengan begitu peserta didik lebih terfokus pada mata pelajaran tersebut dan akan terjadi belajar mengajar yang menyenangkan dan tidak menjenuhkan. Tanpa adanya kreatifitas dan kemampuan guru dalam metode mengajar tersebut peserta didik akan merasa jenuh dan membosankan.

Implementasi strategi pembelajaran Aqidah Akhlak dengan Quantum Teaching meningkatkan pemahaman peserta didik dan akan meningkatkan minat belajar peserta didik dalam proses pembelajaran Aqidah Akhlak. Sehingga dengan metode ini peserta didik akan lebih mudah dalam memahami isi materi pelajaran dan tertarik untuk mendengarkan dan mengamalkan dalam kehidupan sehari-hari.

Berdasarkan latar belakang di atas, maka peneliti mengangkat dan meneliti tentang pembelajaran Quantum Teaching, yang berjudul: Pengaruh Quantum Teaching terhadap Minat Belajar Aqidah Akhlak peserta didik di MTs Pondok Pesantren DDI Manahilil Ulum Kaballangan Kabupaten Pinrang. 


\section{METODE}

Jenis penelitian ini adalah penelitian kuantitatif. Penelitian ini merupakan penelitian lapangan (field research). Bila dilihat dari jenis datanya, penelitian ini termasuk penelitian kuantitatif, karena berusaha mendapatkan data yang objektif, valid, dan reliable dengan menggunakan data yang berbentuk angka, atau data kuantitatif, yang diangkakan. (Sugiyono, 2010). Variabel yang dikaji dalam penelitian ini adalah variabel independen variabel bebas) dan variabel dependen variabel terikat). Variabel independen adalah intensitas pelaksanaan Quantum Teaching yang diberi simbol X dan variabel dependen adalah tingkat minat belajar Aqidah Akhlak peserta didik yang diberi simbol Y. Penelitian ini akan dilaksanakan pada bulan November dan Desember 2017. Lokasi yang menjadi tempat penelitian ini adalah Madrasah Tsanawiyah yang berada di kompleks Pondok Pesantren DDI Manahilil Ulum Kaballangan yang terletak di Jalan. Poros Pinrang-Polman Kabupaten Pinrang.

Adapun yang menjadi populasi dalam penelitian ini adalah semua peserta didik MTs Pondok Pesantren DDI Manahilil Ulum Kaballangan sebanyak 150 orang dengan 7 rombongan belajar. Penentuan sampel dalam penelitian ini menggunakan teknik purposive sampling, yaitu pengambilan sampel karena pertimbangan tertentu. Jadi sampel penelitian adalah sebanyak semua kelas VIII yaitu sebanyak 65 orang dengan pertimbangan kelas IX sementera dalam persiapan Ujian Nasional, sedangkan kelas VII tidak dilibatkan karena pihak MTs Pondok Pesantren DDI Manahilil Ulum Kaballangan tidak merekomendasikan menjadi objek maupun subjek penelitian.

\section{PEMBAHASAN}

\section{Pelaksanaan Quantum Teaching}

Dalam memanfaatkan metode pembelajaran Quantum Teaching banyak sekali permasalahan yang dihadapi oleh guru. Bahkan menurut sebagian guru menggunakan metode pembelajaran menambah beban 
guru, hal ini karena mereka tidak mampu menggunakan metode tersebut. Kemudian pada kenyataannya di lembaga pendidikan formal banyak dijumpai kurang kreatifnya guru dalam mengunakan metode pembelajaran yang dikembangkan sendiri. Sehingga banyak dijumpai guru yang menggunakan metode ceramah dalam mengajar tanpa didampingi dengan metode yang mendukung.

Selain itu, pada lembaga pendidikan tertentu belum semua guru yang ada di madrasah memanfaatkan sumber belajar secara optimal. Masih banyak guru yang mengandalkan cara mengajar dengan paradigma lama, dimana guru merasa satu-satunya sumber belajar bagi peserta didik, inilah yang terjadi pada kebanyakan guru-guru di Indonesia. Di mana sumber belajar yang sudah tersedia (learning resources by utilization), juga belum sepenuhnya dimanfaatkan untuk keperluan pembelajaran. Padahal banyak sumber belajar yang dapat dimanfaatkan oleh guru guna membantu proses pembelajarannya. Di samping memanfaatkan sumber belajar yang ada, guru dituntut untuk mencari dan merencanakan sumber belajar lainnya baik hasil rancangan sendiri ataupun sumber yang sudah ada di sekitar sekolah dan masyarakat. Akibat masih banyaknya guru yang kurang berminat menggunakan metode pembelajaran berdampak pada pola pembelajaran yang monoton dan menjenuhkan.

Kecocokan antara materi pembelajaran dengan metode belum tentu akan menghasilkan proses pembelajaran yang baik apabila guru tidak menyampaikan materi melalui metode pembelajaran dengan baik pula. Karena itu, kadang kala guru akan merasa kurang tertarik untuk memanfaatkan metode pembelajaran Quantum Teaching karena membutuhkan keterampilan dan proses lama untuk mencerna materi pembelajaran.

Dalam proses penelitian, beberapa temuan-temuan dapat diidentifikasi yaitu, sebagian guru yang bisa menggunakan metode Quantum Teaching, alasan penggunaan Quantum Teaching jika ada materi yang susah untuk dijelaskan secara verbal. Penggunaan pembelajaran 
Quantum Teaching telah digunakan di MTs Pondok Pesantren DDI Manahilil Ulum Kaballangan, walaupun intensitas penggunaan Quantum Teaching masih kurang hanya 1 sampai 2 orang guru saja, dikarenakan pengatahuan tentang metode Quantum Teaching masih kurang.

Quantum Teaching merupakan sebuah strategi untuk mempraktekkan Quantum learning di ruang-ruang kelas, berusaha memberikan kiat-kiat, petunjuk, dan seluruh proses yang dapat menghemat waktu, mempertajam pemahaman dan daya ingat, membuat belajar sebagai suatu proses yang menyenangkan dan bermanfaat. Berdasarkan tujuan dari proses pembelajaran, maka dapat diambil sebuah kesimpulan bahwa untuk dapat mendapatkan wawasan yang luas, pembentukan sikap dan memberikan keterampilan, konsep Quantum Teaching inilah langkah atau strategi yang komprehensif untuk meraih tujuan tersebut.

\section{Tingkat Minat Belajar Aqidah Akhlak Peserta Didik di MTs Pondok Pesantren DDI Manahilil Ulum Kaballangan Kabupaten Pinrang}

Minat yang ada pada diri peserta didik sangat penting dalam kegiatan belajar. Ada tidaknya minat seseorang individu untuk belajar sangat berpengaruh dalam proses aktivitas belajar itu sendiri. Jika ciri-ciri tersebut terdapat pada seorang peserta didik berarti peserta didik tersebut memiliki minat belajar yang cukup kuat yang dibutuhkan dalam aktifitas belajarnya. Dari pendapat tersebut dapat disimpulkan bahwa peserta didik yang memiliki minat tinggi dalam belajar akan menunjukkan hal-hal seperti; keinginan mendalami materi, ketekunan dalam mengerjakan tugas, keinginan berprestasi, einginan untuk maju

Sedangkan indikator minat belajar adalah: adanya hasrat dan keinginan berhasil, adanya dorongan dan kebutuhan dalam belajar, adanya harapan dan cita-cita masa depan, adanya penghargaan dalam belajar, adanya kegiatan yang menarik dalam belajar, adanya lingkungan belajar yang kondusif. 
Berdasarkan sebaran angket yang dibagikan kepada peserta didik pada penelitian ini, menunjukkan adanya sikap yang beragam tentang intensitas pelaksanaan Quantum Teaching dalam Pembelajaran Aqidah Akhlak di MTs Pondok Pesantren DDI Manahilil Ulum Kaballangan Kabupaten Pinrang. Teknik analisis statistik deskriptif dimaksudkan untuk mengetahui gambaran umum data, cara penyajian data, dan cara meringkas data hasil perhitungan sesuai dengan tujuan penelitian dan untuk mengetahui gambaran umum variabel. Penyajian data dimaksudkan untuk mendeskripsikan penggunaan tabel distribusi frekuensi.

Distribusi frekuensi skor variabel minat belajar Aqidah Akhlak di MTs Pondok Pesantren DDI Manahilil Ulum Kaballangan Kabupaten Pinrang dapat dilihat pada tabel berikut ini:

Tabel Distribusi frekuensi Minat Belajar Aqidah Akhlak

\begin{tabular}{|c|r|r|r|r|}
\hline & $\begin{array}{c}\text { Frequenc } \\
\mathrm{y}\end{array}$ & Percent & $\begin{array}{c}\text { Valid } \\
\text { Percent }\end{array}$ & $\begin{array}{c}\text { Cumulative } \\
\text { Percent }\end{array}$ \\
\hline Valid 60 & 1 & 1,5 & 1,5 & 1,5 \\
65 & 6 & 9,2 & 9,2 & 10,8 \\
70 & 1 & 1,5 & 1,5 & 12,3 \\
72 & 2 & 3,1 & 3,1 & 15,4 \\
75 & 3 & 4,6 & 4,6 & 20,0 \\
76 & 1 & 1,5 & 1,5 & 21,5 \\
77 & 1 & 1,5 & 1,5 & 23,1 \\
78 & 2 & 3,1 & 3,1 & 26,2 \\
79 & 4 & 6,2 & 6,2 & 32,3 \\
80 & 7 & 10,8 & 10,8 & 43,1 \\
81 & 5 & 7,7 & 7,7 & 50,8 \\
82 & 5 & 7,7 & 7,7 & 58,5 \\
83 & 2 & 3,1 & 3,1 & 61,5 \\
84 & 3 & 4,6 & 4,6 & 66,2 \\
85 & 9 & 13,8 & 13,8 & 80,0 \\
86 & 1 & 1,5 & 1,5 & 81,5 \\
87 & 2 & 3,1 & 3,1 & 84,6
\end{tabular}




\begin{tabular}{|l|r|r|r|r|}
\hline 89 & 1 & 1,5 & 1,5 & 86,2 \\
93 & 1 & 1,5 & 1,5 & 87,7 \\
95 & 1 & 1,5 & 1,5 & 89,2 \\
96 & 1 & 1,5 & 1,5 & 90,8 \\
98 & 3 & 4,6 & 4,6 & 95,4 \\
99 & 1 & 1,5 & 1,5 & 96,9 \\
100 & 2 & 3,1 & 3,1 & 100,0 \\
Total & 65 & 100,0 & 100,0 & \\
\hline
\end{tabular}

Diagram histogram pada Minat Belajar Aqidah Akhlak dapat dilihat pada gambar 4.2 berikut ini:

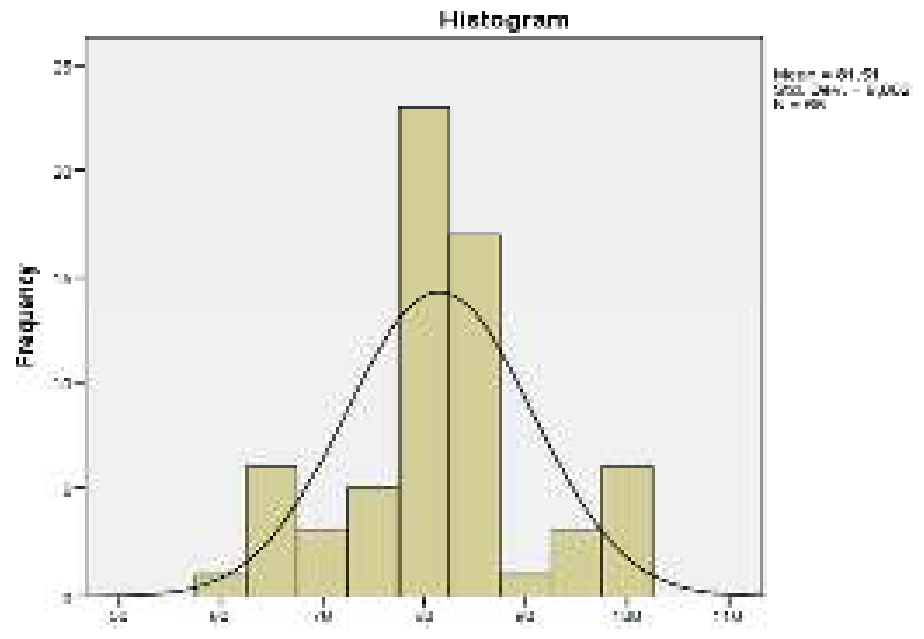

Gambar Histogram Minat Belajar Aqidah Akhlak

Tabel di atas menunjukkan bahwa 25 butir pertanyaan angket yang disebar ke 65 responden di MTs Pondok Pesantren DDI Manahilil Ulum Kaballangan Kabupaten Pinrang, tentang minat belajar Aqidah Akhlak (variabel Y).

Skor total variabel minat belajar Aqidah Akhlak di MTs Pondok Pesantren DDI Manahilil Ulum Kaballangan Kabupaten Pinrang (variabel Y) yang diperoleh dari hasil penelitian adalah 5298, skor teoritik tertinggi 
variabel ini setiap responden adalah $25 \times 4=100$, karena jumlah responden 65 orang, maka skor kriterium adalah $100 \times 65=6500$. Sehingga, minat belajar Aqidah Akhlak di MTs DDI kaballangan Kabupaten Pinrang (variabel Y) adalah $5298: 6500=0,815$ atau 81,5 persen dari kriterium yang ditetapkan. Jadi dapat disimpulkan bahwa minat belajar Aqidah Akhlak di MTs Pondok Pesantren DDI Manahilil Ulum Kaballangan Kabupaten Pinrang (variabel $Y$ ) termasuk kategori tinggi. Hal tersebut sesuai dengan hasil pengamatan di lapangan bahwa minat belajar Aqidah Akhlak di MTs Pondok Pesantren DDI Manahilil Ulum Kaballangan Kabupaten Pinrang telah berjalan secara baik karena guru menggunakan metode dan media pembelajaran yang baik.

Berdasarkan hasil observasi dengan peserta didik dapat disimpulkan bahwa minat belajar memberikan dampak yang signifikan ketika menggunakan metode dan media pembelajaran yang relevan. Penggunaan metode dan media pembelajaran relevan perlu dibantu dengang media yang relevan pula. Minat belajar sangat penting ditumbuhkan di dalam diri peserta didik agar mereka semua memperoleh kesuksesan dalam mencapai kompetensi yang diharapkan, baik berupa pengetahuan, sikap ataupun keterampilan. Dorongan yang berasal dari dalam diri peserta didik akan memberikan kekuatan yang luar biasa untuk membuat mereka gigih dalam belajar. Jika peserta didik telah memiliki minat belajar yang kuat dalam dirinya, maka ia tidak terlalu membutuhkan dorongan dari luar (minat ekstrinsik) lagi. Memang sebaiknya minat ekstrinsik tetap diberikan untuk menjaga agar minat belajar tetap bersemayam dalam diri peserta didik. Misalnya, dengan memberikan pujian, penghargaan, atau hadiah, atau hal-hal lainnya. Minat ekstrinsik yang diberikan dengan tepat akan memperkuat minat belajar yang telah ada, atau dapat menumbuhkan minat belajar yang sebelumnya tidak peserta didik miliki. 


\section{Pengaruh Quantum Teaching terhadap Minat Belajar Aqidah Akhlak Peserta Didik di MTs Pondok Pesantren DDI Manahilil Ulum Kaballangan Kabupaten Pinrang.}

Berdasarkan hasil uji hipotesis bahwa terdapat pengaruh Quantum Teaching terhadap minat belajar Aqidah khlak di MTs Pondok Pesantren DDI Manahilil Ulum Kaballangan Kabupaten Pinrang. Akan tetapi pengaruh antara variabel $\mathrm{x}$ dan variabel y mempunyai pengaruh sedang. Hal tersebut menunjukkan bahwa intensitas pelaksanaan Quantum Teaching belum maksimal dan masih jarang digunakan dalam proses pembelajaran sehingga tidak terlalu berdampak langsung terhadap peningkatan minat belajar peserta didik.

Menurut peneliti intensitas pelaksanaan Quantum Teaching mempunyai pengaruh terhadap minat belajar peserta didik, jika guru memilih metode yang tepat, kemudian harus dilihat dari usia dan kelas peserta didik, serta penjelasan mengenai metode tersebut, sehingga minat belajar peserta didik bisa meningkat dan dapat meningkatkan nilai dan prestasi peserta didik MTs DDI Manahilil Ulum Kaballangan Kabuaten Pinrang.

Temuan penting penelitian ini adalah: bahwa keterampilan berpikir kritis peserta didik yang mengikuti pembelajaran dengan model pembelajaran Quantum Teaching lebih tinggi dibandingkan dengan peserta didik yang mengikuti pembelajaran dengan model pembelajaran konvensional. Artinya, bahwa model pembelajaran Quantum Teaching mempunyai pengaruh yang signifikan terhadap peningkatan minat belajar. Oleh karena itu, temuan penelitian ini memberi implikasi terhadap aplikasi model pembelajaran, baik model pembelajaran Quantum Teaching maupun model konvensional dalam proses pembelajaran. Temuan ini, menimbulkan beberapa implikasi, yaitu:

Pertama, guru sebagai ujung tombak pembelajaran, harus memiliki pengetahuan dan keterampilan dalam memilih, mengembangkan, dan menerapkan model pembelajaran yang sesuai dengan rumpun dan 
karakteristik disiplin ilmunya. Hal ini sesuai dengan misi pembelajaran yaitu membekali dan melatihkan seperangkat pengetahuan, nilai, moral, etika dan keterampilan-keterampilan dasar sebagai warga negara yang bertanggungjawab bagi kelangsungan dan keutuhan negaranya. Pendekatan pembelajaran yang dapat mengkondisikan dan memotivasi peserta didik untuk mengakses informasi yang diperlukan untuk pengembangan potensi diri dan mencintai budaya secara proporsional adalah model pembelajaran Quantum Teaching. Pembelajaran dengan model Quantum Teaching akan menuntun peserta didik untuk memahami konsep yang diperlukannya sejak dini dalam suasana kelas yang benarbenar merupakan potret yang nyata dari masyarakat.

Kedua, model pembelajaran Quantum Teaching dapat diaplikasikan dalam perencanaan dan pelaksanaan model pembelajaran yang selama ini diterapkan, sehingga menambah banyak variasi model pembelajaran yang dapat diterapkan oleh guru. Bagi seorang guru membuat perencanaan pelaksanaan pembelajaran merupakan hal yang sangat penting dan suatu kewajiban, karena persiapan yang baik adalah awal dari keberhasilan.

Ketiga, Temuan penelitian ini adalah bahwa ternyata keterampilan berpikir kritis memiliki kontribusi yang signifikan terhadap minat belajar dengan menggunakan model Quantum Teaching, namun hal ini tentu memerlukan pembuktian lebih jauh, sehingga diperlukan penelitian lanjut untuk pengujian model ini secara lebih luas.

\section{SIMPULAN}

Berdasarkan uraian sebelumnya dapat disimpulkan isi artikel ini sebagai berikut:

Intensitas pelaksanaan Quantum Teaching dalam pembelajaran Aqidah Akhlak di MTs Pondok Pesantren DDI Manahilil Ulum Kaballangan Kabupaten Pinrang berdasarkan hasil perhitungan angket diperoleh = 0,661 atau 66,1 persen dari kriterium yang ditetapkan. Jadi dapat disimpulkan bahwa intensitas pelaksanaan Quantum Teaching dalam pembelajaran Aqidah Akhlak termasuk kategori rendah. Hal terjadi karena 
hanya beberapa dari guru saja yang memahami dan menguasai metode pembelajaran Quantum Teaching.

Hasil perhitungan angket yang disebar ke 65 responden di MTs Pondok Pesantren DDI Manahilil Ulum Kaballangan Kabupaten Pinrang, tentang minat belajar Aqidah Akhlak peserta didik adalah 0,815 atau 81,5 persen dari kriterium yang ditetapkan. Jadi dapat disimpulkan bahwa minat belajar Aqidah Akhlak peserta didik di MTs Pondok Pesantren DDI Manahilil Ulum Kaballangan Kabupaten Pinrang (variabel Y) termasuk kategori tinggi.

Hasil uji hipotesis dapat disimpulkan bahwa pelaksanaan Quantum Teaching terdapat pengaruh dengan minat belajar Aqidah Akhlak. Jadi dapat disimpulkan bahwa minat belajar Aqidah Akhlak peserta didik di MTs Pondok Pesantren DDI Manahilil Ulum Kaballangan Kabupaten Pinrang (variabel Y) termasuk kategori tinggi. Berdasarkan hasil perhitungan dan tabel koefisien determinasi, variabel $\mathrm{x}$ dan variabel $\mathrm{y}$ mempunyai pengaruh yaitu 0,362 atau 36,2 persen, dan sisanya 64,8 persen dipengaruhi oleh variabel lainnya.

\section{REFERENCE}

(1) Abdullah, S. (2016, December 6). KAJIAN REKONSTRUKSI "BUDAYA SIRI" BUGIS DITINJAU DARI PENDIDIKAN ISLAM. AL-ISHLAH : Jurnal Studi Pendidikan, 14

(2) Arikunto, S. (1992). Prosedur penelitian: Suatu pendekatan praktik. Rineka Cipta.

(3) Dalle, H. A. (2015, August 20). WACANA BAHASA INGGRIS BERDASARKAN KETERAMPILAN BERBAHASA KELAS X MAN 2 PAREPARE. AL-ISHLAH : Jurnal Studi Pendidikan, 13

(4) Hadi, S. (2004). Metodologi research jilid I. Yogyakarta: Andi, 94, 95.

(5) Halik, A. (2016, December 6). PARADIGMA PENDIDIKAN ISLAM DALAM TRANSFORMASI SISTEM KEPERCAYAAN TRADISIONAL. AL-ISHLAH : Jurnal Studi Pendidikan, 14

(6) K, H. H. (2016, December 6). PENDIDIKAN ISLAM PADA MASA DAULAH USMANI (Sejak Sultan Mahmud II Sampai Menjadi 
Kuriositas: Media Komunikasi Sosial dan Keagamaan

Vol. 11 No.1, Juni 2018: h.19-32

Negara Turki Modern oleh Mustafa Kemal) AL-ISHLAH : Jurnal Studi Pendidikan, 14

(7) Margono, S. (2005). Metodologi penelitian pendidikan. Jakarta: Rineka Cipta.

(8) Ridwan, S. (n.d.). H.(2010). Pengantar Statistik Untuk Penelitian Pendidikan, Sosial, Ekonomi, Komunikasi, Dan Bisnis. Bandung: Alyabeta.

(9) Sugiyono, P. D. (2010). Metode penelitian pendidikan. Pendekatan Kuantitatif. 